\title{
Pediatric cataracts: clinical aspects, frequency of strabismus and chronological, etiological, and morphological features
}

\author{
Catarata pediátrica: aspectos clínicos, frequência de estrabismo e características cronológicas, \\ etiológicas e morfológicas
}

Márcia Beatriz Tartarella ${ }^{1}$, Gloria Fátima Britez-Colombil ${ }^{1}$, Suanne Milhomem ${ }^{1}$, Márcia Cordeiro Emery Lopes ${ }^{1}$, João Borges Fortes Filho ${ }^{2}$

\begin{abstract}
Purpose: This study aimed to evaluate the frequency of strabismus and chronological, etiological, and morphological features in patients with pediatric cataracts. Methods: Medical records of pediatric patients were evaluated at the Congenital Cataract Section, Department of Ophthalmology, Federal University of São Paulo, from 2001 to 2011. Patients with congenital cataract or developmental cataract were included. The patients with traumatic cataract, cataract secondary to uveitis, radiation or drugs, aphakic or pseudophakic patients who underwent surgery in another hospital, patients with glaucoma, non-lenticular leukocorias (retinoblastoma, retinopathy of prematurity, prelenticular leukocorias), and lens subluxation were excluded from the study. The following outcomes were evaluated: frequency of chronological, etiological, and morphological features, laterality, and occurrence of associated strabismus.
\end{abstract}

Results: A total of 207 patients were included. One hundred and seventeen patients (56.5\%) had congenital cataract and 90 patients (43.5\%) had developmental cataract. One hundred and nine patients (52.6\%) had unilateral cataract. In terms of morphology, 72 children (33.8\%) had zonular cataract and 66 (31.9\%) had total cataract. Idiopathic cataract affected 150 patients (72.5\%). There were 108 patients (52.2\%) with strabismus, mainly secondary esotropia.

Conclusion: Idiopathic etiology was the most frequent cause in this group of patients. Zonular cataract was the main morphological type of cataract in the study. Unilateral cataract occurred more frequently in patients with persistent fetal vasculature (PFV). Strabismus presented in $52 \%$ of the patients. The current analysis may help establish an earlier and more accurate diagnosis of pediatric cataracts.

Keywords: Cataract; Congenital; Diagnosis; Strabismus; Persistent fetal circulation syndrome; Humans; Pediatric

\section{RESUMO}

Objetivos: Avaliar as frequências do estrabismo e as características cronológica, etiológica e morfológica das cataratas pediátricas.

Método: Estudo retrospectivo dos prontuários de crianças atendidas no Ambulatório de Catarata Congênita do Departamento de Oftalmologia da Universidade Federal de São Paulo no perío do entre 2001 e 2011. Foram incluídos pacientes com diagnóstico de catarata congênita ou de desenvolvimento. Foram excluídos os pacientes com catarata traumática; secundárias a uveíte, radiação ou medicamentos; pacientes operados em outro serviço; pacientes com glaucoma; leucocorias não cristalinianas (retinoblastoma, retinopatia da prematuridade, leucocorias pré-cristalinianas), e com sub-luxação do cristalino. Foram avaliadas: as frequências cronológicas, etiológicas e morfológicas das cataratas; a lateralidade e a ocorrência de estrabismo associado nestes pacientes. Resultados: Foram incluídos 207 pacientes. Cento e dezessete (56,5\%) apresentavam catarata congênita e $90(43,5 \%)$ apresentavam catarata de desenvolvimento. Cento e nove $(52,6 \%)$ pacientes eram portadores de catarata unilateral. Quanto à morfologia, 72 crianças $(33,8 \%)$ apresentavam catarata zonular e $66(31,9 \%)$ apresentavam catarata total. A etiologia idiopática foi a mais frequente $(72,5 \%)$ afetando 150 pacientes. Foram observados 108 pacientes (52,2\%) com estrabismo associado, especialmente endotropias secundárias.

Conclusões: Aetiologia idiopática foi a maisfrequentenesteestudo. Otipo morfológico zonular foi o mais frequentemente diagnosticado. Cataratas unilaterais ocorreram mais frequentementeem pacientes com persistência da vasculatura fetal. Oestrabismo associado ocorreu em 52\% dos pacientes. A análise dos resultados deste estudo pode contribuirpara diagnosticar a cataratapediátrica precocementeedemodo mais preciso.

Descritores: Catarata/congênito; Catara/diagnóstico; Estrabismo; Síndrome da persistência do padrão de circulação fetal; Humanos; Criança

\section{INTRODUCTION}

Cataract is a major cause of visual impairment during childhood. Pediatric cataract often leads to amblyopia and secondary strabismus $^{(1-4)}$. Early diagnosis and treatment to prevent lateral geniculate body atrophy during the critical period of visual development is important for the visual prognosis of children affected by cataract ${ }^{(5-7)}$.

Pediatric cataracts are classified according to their time of onset (chronological), etiology, and morphology. The chronological classification is based on the time of onset of the opacity in the lens ${ }^{(8)}$. When lens opacity is detected within the first 3 months of life after birth, the disease is classified as congenital cataract. When the diagnosis or the onset of opacity occurs after 3 months of life, the disease is classified as developmental cataract or infantile cataract. Early developmental cataract occurs within the first 12 months of life and late developmental cataract occurs after the first year of life ${ }^{(8-10)}$. The chronological classification helps establish the visual prognosis in patients.

Pediatric cataracts have different etiologies including hereditary, secondary to congenital infections associated with systemic syndromes and ocular abnormalities [aniridia, persistent fetal vasculature (PFV), Peters anomaly, anterior segment dysgenesis, prior ocular surgery and uveitis], secondary to external agents, such as drugs (e.g., corticosteroids), radiotherapy, or environmental factors, and ocular
Funding: No specific financial support was available for this study.

Disclosure of potential conflicts of interest: None of the authors have any potential conflicts of interest to disclose.

Corresponding author: João Borges Fortes Filho. Rua Ramiro Barcelos, 2.350 - Porto Alegre (RS) 90035-903 - Brazil - E-mail: jbfortes@prorop.com.br 
trauma ${ }^{(10-14)}$. Cataracts with undetermined causes are classified as idiopathic(15).

Morphologically, pediatric cataracts are classified into total cataract, zonular cataract (lamellar, pulverulent, nuclear, sutural), capsular cataract (anterior subcapsular, posterior subcapsular, lenticonus), and membranous cataract ${ }^{(16)}$. When associated with syndromes, metabolic diseases, or inherited cataracts, the morphological features of the cataract may provide clues to the possible etiology ${ }^{(14)}$

The objective of the present study was to evaluate the frequency of strabismus as well as the chronological, etiological, and morphological features of the disease in pediatric cataract patients.

\section{METHODS}

This retrospective and descriptive study was conducted at the Congenital Cataract Section, Department of Ophthalmology, Universidade Federal de São Paulo (UNIFESP), Brazil, from February 2001 to January 2011. Patients diagnosed with congenital or developmental cataract were included in the study. Exclusion criteria were the following: traumatic cataract, cataract secondary to uveitis, radiation, or drugs, aphakic or pseudophakic patients who underwent surgery at an unrelated service, patients with glaucoma, non-lenticular leukocorias (retinoblastoma, retinopathy of prematurity, prelenticular leukocorias), and patients with lens subluxation.

Data collected from the patient files at the first presentation included gestational, familial, and personal health information. Eye examination included analysis of the cataract morphology at biomicroscopy. Patients underwent ocular ultrasound when the opacity of the lens prevented the examination of the ocular fundus by binocular indirect ophthalmoscopy. For the outcomes evaluated, we collected the following data: time of onset of the cataract, laterality, etiology, morphology, and evaluated the ocular alignment by Hirschberg test. We also performed strabismus detection with the help of cover test. The visual acuity was assessed by the age-paired tests, Teller cards acuity test, Lea Hyvarigen test, or Snellen visual acuity test.

Cataract was classified chronologically according to the time when the disease was detected. Cases showing lens opacity within the first 3 months of life following birth were classified as congenital cataracts. Cases in which diagnosis or the onset of opacity occurred after the first 3 months of life were classified as developmental cataract. To establish the etiology of the disease, children were referred to a pediatrician for clinical evaluation and routine tests. Children up to 18 months of age were requested to undergo routine serologic tests for the detection of any possible toxoplasmosis, rubella, syphilis, and cytomegalovirus. The following laboratory tests were performed routinely: complete blood count test, blood glucose test, neonatal heel prick test (Guthrie test), and total serum calcium test. Patients with cataracts of suspected genetic etiology were referred to the Section of Genetics of the Pediatric Department at the UNIFESP. After the required tests were performed at the institute, the patients with no identifiable cause for cataracts were included in the group of idiopathic etiology.

Cataract was classified according to the morphology as total (Figure 1), zonular, polar, capsular, and membranous. Zonular cataracts, which effect the fetal nucleus of the lens, were further classified as lamellar (Figure 2), pulverulent (Figure 3), nuclear (Figure 4), and sutural. According to the site of lens opacity, polar cataracts were classified as anterior, posterior, or pyramidal (Figure 5). Capsular cataracts were further classified as anterior, posterior, and lenticonus. When multiple morphological types of cataract co-exist in the same child or in the same eye, they are considered as mixed cataract.

\section{RESULTS}

We analyzed a total of 428 medical files. However, only 207 of these files contained complete medical history, time of onset of the disease, etiology, and morphology of the cataract. Therefore, only these 207 cases were included in our study. Age of the patients ranged from 19 days to 12 years.

Of the 207 patients included in the study, 117 had congenital cataract (56.5\%), and 90 patients (43.5\%) had developmental cataract. At the time of diagnosis, 109 patients (52.6\%) had unilateral cataract. Of these patients, $51.3 \%$ had congenital cataract and $54.4 \%$ had developmental cataract. The frequencies of congenital and developmental cataracts, according to their laterality, are shown in table 1.

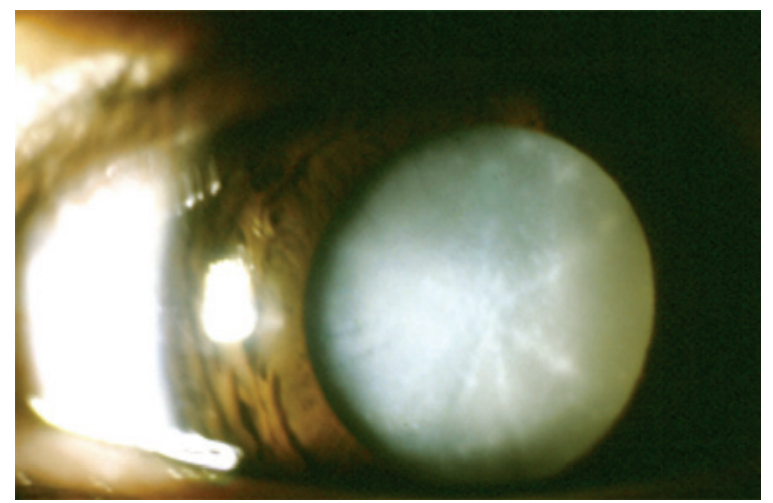

Figure 1. Total cataract.

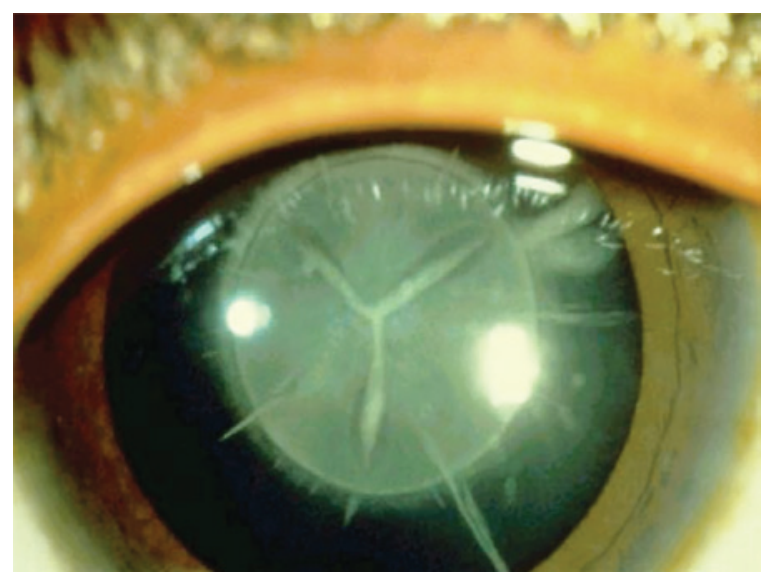

Figure 2. Lamellar cataract.

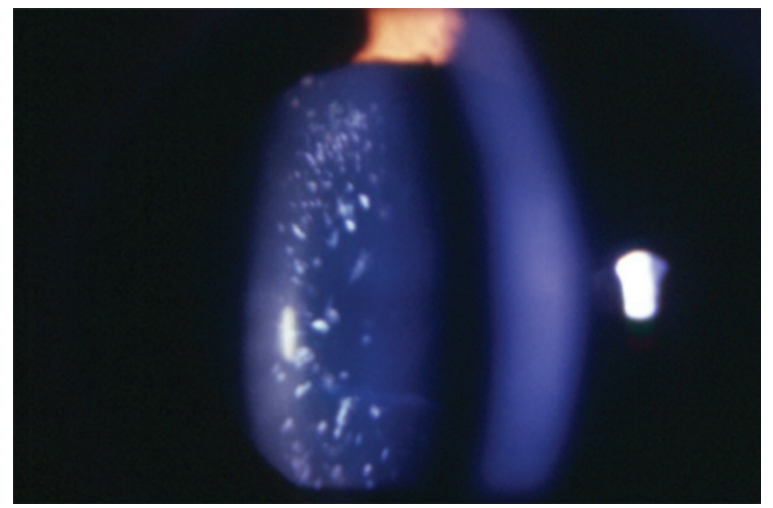

Figure 3. Pulverulent cataract. 
Of the 207 patients, 150 (72.5\%) had idiopathic cataract. Among these 150 cases, 74 (49.3\%) had bilateral cataract. Infectious etiology was present in 18 patients (8.7\%). Congenital rubella occurred in 14 patients (6.8\%) and accounted for $77.8 \%$ of the cases in which infection was identified as the etiology. PFV was diagnosed in 17 patients (8.2\%), of which 16 had unilateral cataract (94.1\%). Familial history of pediatric cataracts was confirmed in 14 cases (6.8\%). Hereditary patterns detected were either autosomal dominant or autosomal recessive. The etiology established in the present study is shown in table 2.

Serum calcium test was performed to detect parathyroid disorders. Total serum calcium was within the normal range in all the patients (between 6.7 and $10.7 \mathrm{mg} / \mathrm{dL}$ ).

Total cataract was diagnosed in 66 patients (31.9\%), whereas 72 cases (33.8\%) had zonular cataract. Among the different types of zonular cataract, lamellar cataract was the most frequent and was

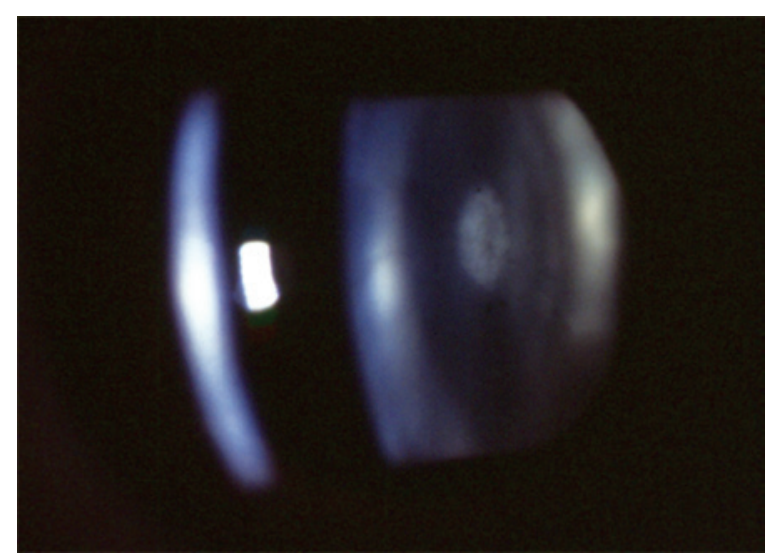

Figure 4. Nuclear cataract.

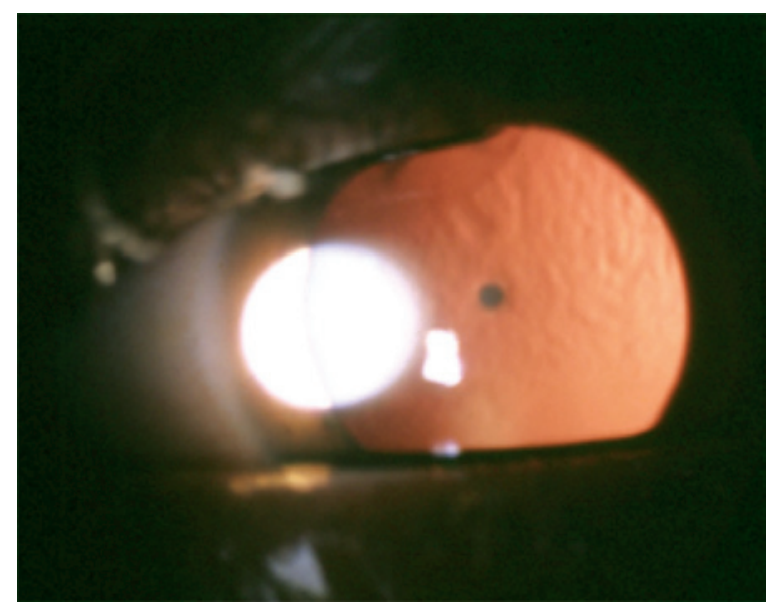

Figure 5. Polar cataract.

Table 1. Distribution of laterality in congenital and developmental cataracts

\begin{tabular}{lrrr}
\hline & Unilateral & Bilateral & \multicolumn{1}{c}{ Total } \\
\hline Congenital cataract & $60(51.3 \%)$ & $57(48.7 \%)$ & $117(56.5 \%)$ \\
Developmental cataract & $49(54.4 \%)$ & $41(45.6 \%)$ & $90(43.5 \%)$ \\
Total & $109(52.6 \%)$ & $98(47.4 \%)$ & $207(100 \%)$ \\
\hline
\end{tabular}

$P=0.976$. detected in 46 cases. As shown in table 3, mixed cataracts were present in 33 patients (15.9\%).

The association between the etiology of detected cataract and the morphological types is shown in table 4. Zonular (60 cases) and total (43 cases) cataracts were more frequent in the idiopathic etiology group. PFV had more cases of posterior capsular cataracts (10 cases) than the entire group.

Strabismus was diagnosed in 108 (52.2\%) patients, of which 65 $(55.55 \%)$ were children with congenital cataracts and 43 were children (47.77\%) with developmental cataracts.

Esotropia and exotropia were diagnosed in 60 (55.6\%) and 48 (44.4\%) patients, respectively. Esotropia was present in 40 (34.2\%) patients with congenital cataracts and 20 (22.22\%) patients with developmental cataracts. Vertical deviations were found in three patients. However, all three cases were associated with horizontal deviation. The distribution of the cases of strabismus among the patients with cataract is shown in table 5 .

Visual acuity ranged from light perception in total cataract cases to $20 / 20$ in lamellar cataracts. Only children with visual acuities worse than 20/70 were selected for surgery.

\section{DISCUSSION}

The present study demonstrated a similar frequency of occurrence of congenital and developmental cataracts (56.5\% vs. $43.5 \%$,

\section{Table 2. Etiology of laterality}

\begin{tabular}{lccc}
\hline Etiology & Unilateral & Bilateral & Total \\
\hline Idiopathic & 76 & 74 & $150(72.5 \%)$ \\
Infectious & 15 & 3 & $18(8.7 \%)$ \\
$\quad$ Congenital rubella & 13 & 1 & $14(77.8 \%$ in the group) \\
Toxoplasmosis & 2 & 2 & $4(22.2 \%$ in the group) \\
Secondary to PFV & 16 & 1 & $17(8.2 \%)$ \\
Hereditary & 1 & 13 & $14(6.8 \%)$ \\
Syndromes & 1 & 7 & $8(3.9 \%)$ \\
Down syndrome & 0 & 6 & $6(75 \%$ in the group) \\
Other & 1 & 1 & $2(25 \%$ in the group) \\
\hline Total of patients & 109 & 98 & $207(100 \%)$ \\
\hline PFV $=$ persistent fetal vasculature & & &
\end{tabular}

Table 3. Morphology of pediatric cataracts and laterality

\begin{tabular}{lccc}
\hline Morphological characteristics & Unilateral & Bilateral & Total \\
\hline Total cataract & 43 & 23 & $66(31.9 \%)$ \\
Zonular & 26 & 46 & $72(33.8 \%)$ \\
Lamellar & 12 & 36 & 48 \\
Pulverulent & 0 & 2 & 2 \\
Nuclear & 8 & 6 & 14 \\
Sutural & 6 & 2 & 8 \\
Capsular & 13 & 3 & $16(7.7 \%)$ \\
Anterior subcapsular & 0 & 0 & 0 \\
Posterior subcapsular & 13 & 3 & 16 \\
Polar & 16 & 4 & $20(9.7 \%)$ \\
Anterior & 1 & 4 & 5 \\
Posterior & 15 & 0 & 15 \\
Mixed & 11 & 22 & $33(15.9 \%)$ \\
\hline Total of patients & 109 & 98 & $207(100 \%)$ \\
\hline
\end{tabular}


Table 4. Analysis of the etiology and morphology of pediatric cataracts

\begin{tabular}{lcccccc}
\hline & Total Cataract & Zonular & Capsular & Polar & Mixed & Total \\
\hline Infectious & 11 & 3 & 0 & 2 & 2 & 18 \\
Syndromes & 4 & 3 & 0 & 0 & 1 & 8 \\
Hereditary & 3 & 6 & 0 & 1 & 4 & 14 \\
PFV & 5 & 0 & 10 & 0 & 2 & 17 \\
Idiopathic & 43 & 60 & 6 & 17 & 24 & 150 \\
\hline Total of patients & 66 & 72 & 16 & 20 & 33 & 207 \\
\hline
\end{tabular}

$\mathrm{PFV}=$ persistent fetal vasculature.

Table 5. Association between pediatric cataract and the occurrence of strabismus

\begin{tabular}{lcccc}
\hline Cataract & Orthophoria & Esotropia & Exotropia & Total \\
\hline Congenital & $52(44.4 \%)$ & $40(34.2 \%)$ & $25(21.3 \%)$ & 117 \\
Developmental & $47(52.2 \%)$ & $20(22.2 \%)$ & $23(25.5 \%)$ & 90 \\
\hline Total of patients & 99 & 60 & 48 & 207 \\
\hline
\end{tabular}

respectively), as well as similar rates of cataract laterality $(47.3 \%$ of bilateral cataract vs. $52.7 \%$ unilateral cataract). Laterality may indicate the etiology. In this study, we found that bilateral cataracts were usually associated with syndromes or a familial history (hereditary) of the disease. Unilateral cataracts occurred more frequently in cases of PFV and congenital rubella. A previous study of unilateral congenital cataracts found that almost all unilateral cases were due to PFV(17).

Analysis of the etiology revealed that idiopathic cataracts occurred most frequently (72.5\%) followed by cataracts caused by congenital infections (8.7\%) such as rubella. In agreement with the results of an earlier study, we found that 17 patients (8.2\%) had cataracts associated with PFV and majority of these cases (16 patients, 94.1\%) had unilateral cataracts ${ }^{(18)}$. Among 8 patients with genetic disorders, 7 had bilateral cataract (87.5\%) and all 8 cases had Down's syndrome. Hereditary cataracts accounted for only $6.8 \%$ of the cases. This rate is substantially lower than an earlier reported study, which noted that nearly one-third of the cases were inherited ${ }^{(19)}$. Further, a study of 85 patients conducted in Tunisia found that $32.5 \%$ of the patients had idiopathic cataract, $42.3 \%$ had hereditary cataract, and $4.7 \%$ had cataract caused by infection ${ }^{(20)}$.

To establish the etiology of pediatric cataracts the routine work up protocol should include tests for metabolic disease markers, urine reducing substance test, and eye examination of relatives (patient's parents, grandparents, and siblings). In the recent years, DNA analysis has been widely used to identify the affected genes. Accordingly, mutations in crystallins and connexins have been identified to play important role in the development of cataracts. To date, more than 30 independent loci have been mapped and identified as playing key roles in inherited cataracts ${ }^{(21-25)}$.

Other measures that could improve the identification of the etiology of pediatric cataracts include a questionnaire regarding exposure to environmental risk factors or chemicals and implementation of polymerase chain reaction (PCR)-based tests to detect viral infection of the lens. We performed serum calcium test to detect parathyroid disorders and found that total serum calcium was normal in all the patients.

Accurate diagnosis of the etiology of pediatric cataract is important for epidemiological studies and future preventive actions.

Pediatric cataracts exhibit substantial heterogeneity. The opacity of the lens may affect the lens nucleus or alternatively the nucleus could remain transparent while the cortex or the lamellae surrounding the nucleus become opaque. The morphological diversity makes the morphological classification a challenging task. Additionally, there exists the possibility for overlapping morphologies. We found that zonular cataracts occurred with the highest frequency, in 72 (33.8\%) patients. Among these cases, the lamellar subtype (Figure 2) was the most common (66.7\%). Total cataract occurred in 66 (31.9\%) patients (Figure 1).

Morphology or laterality of pediatric cataract may be indicative of its etiology. Hereditary cataracts display a variety of phenotypes, more frequently display a zonular morphology (Figure 3), and are usually bilateral. In most cases, the opacity of the lens caused by PFV are unilateral posterior subcapsular, which progress into complete opacity of the lens. We found that among the PFV patients, 52.94\% had posterior subcapsular cataract (Table 4). Nuclear cataract (Figure 4) is usually detected at birth, whereas lamellar cataract (Figure 2) develops at a later stage and can be progressive. Visual prognosis may depend on the morphological type, with less favorable outcomes in cases of total cataracts ${ }^{(26)}$.

As described earlier, strabismus was diagnosed in 108 (52.2\%) patients. A total of 65 (55.55\%) children with congenital cataracts and 43 children (47.77\%) with developmental cataracts had strabismus; this suggested that the earlier the onset of the visual deprivation, the greater the involvement of the visual pathways. Esotropia was more frequent in patients with congenital cataracts (34.2\%) (Table 5).

In a previous study of children with congenital cataract who underwent lensectomy, strabismus was present in $54.8 \%$ of the patients and esotropia accounted for $64.7 \%$ of the cases $^{(27)}$.

A study of ocular alignment after surgery conducted in 41 children with dense cataracts, among which 27 (66\%) developed strabismus, demonstrated that congenital cataract was associated with a greater risk for the occurrence of strabismus than developmental cataract. The study concluded that laterality and the time of onset of the cataract were not significant risk factors for the development of strabismus. Further, the study showed that there is a significant risk for the occurrence of strabismus in cases where the visual deprivation lasted longer than 6 weeks ${ }^{(28)}$. A separate study that analyzed 113 patients who underwent surgery for developmental cataract found strabismus in 39 patients (34\%), a higher incidence rate than that of the general population. The authors concluded that strabismus might have an impact on visual acuity in cases of unilateral and total cataracts. The occurrence of strabismus in children with cataract can be related to four factors that could affect the visual perception: reduced vision in one eye with the presence of amblyopia, asymmetry in visual acuity in bilateral cataract cases, loss of stereopsis, and anisometropia. Parents must be made aware that these patients may have difficulty in viewing three-dimensional (3D) images in movies and computers ${ }^{(29)}$.

Programs implementing the red reflex test to detect leukocoria in newborn and the administration of visual acuity screening tests in pre-school children are of importance. These tests will enable the early diagnosis of pediatric cataract, particularly since approximately $50 \%$ of pediatric cataract patients do not present with strabismus and might not be referred on time for appropriate treatment ${ }^{(30)}$.

\section{CONCLUSIONS}

Idiopathic etiology was the most frequent cause of cataract in the group of patients studied. Zonular cataracts were the main morphological type of cataract. Unilateral cataracts occurred more frequently in cases of PFV. Strabismus was present in $52 \%$ of the patients. The results of our study may help establish a program for earlier and more accurate diagnosis of pediatric cataracts.

\section{REFERENCES}

1. Furtado JM, Lansingh VC, Carter MJ, Milanese MF, Pena BN, Ghersi HA, et al. Causes of blindness and visual impairment in Latin America. Surv Ophthalmol. 2012;57(2):149-77.

2. Muhit MA, Shah SP, Gilbert CE, Foster A. Causes of severe visual impairment and blindness in Bangladesh: a study of 1935 children. Br J Ophthalmol. 2007:91(8):1000-4

3. Limburg H, Gilbert C, Hon do N, Dung NC, Hoang TH. Prevalence and causes of blindness in children in Vietnam. Ophthalmology. 2012;119(2):355-61. 
4. Gilbert C. Changing challenges in the control of blindness in children. Eye (Lond). 2007; 21(10):1338-43.

5. Zetterstrom C, Lundvall A, Kugelberg M. Cataracts in children. J Cataract Refract Surg 2005:31(4):824-40.

6. Khanna RC, Foster A, Krishnaiah S, Mehta MK, Gogate PM. Visual outcomes of bilateral congenital and developmental cataracts in young children in south India and causes of poor outcome. Indian J Ophthalmol. 2013;61(2):65-70.

7. Birch EE, Cheng C, Stager DR Jr, Weakley DR Jr, Stager DR Sr. The critical period for surgical treatment of dense congenital bilateral cataracts. J AAPOS. 2009;13(1):67-71. Comment in: J AAPOS. 2009;13(5):527-8; author reply 528.

8. Lambert SR, Drack AV. Infantile cataracts. Surv Ophthalmol. 1996;40(6):427-58

9. Verçoza IC, Tartarella MB. Catarata na criança. Fortaleza: Celigrafica; 2008

10. Cordes FC. Types of congenital cataract. Am J Ophthalmol. 1947;30(4):397-420.

11. Raghu H, Subhan S, Jose RJ, Gangopadhyay N, Bhende J, Sharma S. Herpes simplex virus-1-associated congenital cataract. Am J Ophthalmol. 2004;138(2):313-4

12. Francois-Fiquet C, Wavreille O, Poli Merol ML, Doco-Fenzy M. Cleft palate and bilatera congenital cataract: a familial observation: a new syndrome? Br J Oral Maxillofac Surg 2012;50(7):e109-12.

13. Kondo Y, Saitsu H, Miyamoto T, Lee BJ, Nishiyama K, Nakashima M, et al. Pathogenic mutations in two families with congenital cataract identified with whole-exome sequencing. Mol Vis. 2013;19:384-9.

14. Chan WH, Biswas S, Ashworth JL, Lloyd IC. Congenital and infantile cataract: etiology and management. Eur J Pediatr. 2012:171(4):625-30.

15. Brandão AM, Tartarella MB. [Unilateral pediatric cataract surgery]. Arq Bras Oftalmol. 2008;71(2):238-41. Portuguese.

16. Verçoza IC, Tartarella MB. Aspectos morfológicos da catarata na criança. In: Verçoza IC, Tartarella MB, editors. Catarata na criança. Fortaleza CE: Celigráfica; 2008. p.50-60.

17. Mullner-Eidenbock A, Amon M, Moser E, Klebermass N. Persistent fetal vasculature and minimal fetal vascular remnants: a frequent cause of unilateral congenital cataracts. Ophthalmology. 2004;111(5):906-13

18. Mullner-Eidenbock A, Amon M, Hauff W, Klebermass N, Abela C, Moser E. Surgery in unilateral congenital cataract caused by persistent fetal vasculature or minimal fetal vascular remnants: age-related findings and management challenges. J Cataract Refract Surg. 2004;30(3):611-9.
19. Zhang $X$, Wang L, Wang J, Dong B, Li Y. Coralliform cataract caused by a novel connexin46 (GJA3) mutation in a Chinese family. Mol Vis. 2012;18:203-10.

20. El Fkih L, Hmaied W, El Hif S, Moalla S, Marakchi S, Tabib N, et al. Congenital cataract etiology. Tunis Med. 2007;85(12):1025-9.

21. Reddy MA, Bateman OA, Chakarova C, Ferris J, Berry V, Lomas E, et al. Characterization of the G91del CRYBA1/3-crystallin protein: a cause of human inherited cataract. Hum Mol Genet. 2004;13(9):945-53.

22. Berry V, Francis P, Reddy MA, Collyer D, Vithana E, MacKay I, et al. Alpha-B crystallin gene (CRYAB) mutation causes dominant congenital posterior polar cataract in humans. Am J Hum Genet. 2001:69(5):1141-5.

23. Francis PJ, lonides A, Berry V, Bhattacharya S, Moore AT. Visual outcome in patients with isolated autosomal dominant congenital cataract. Ophthalmology. 2001;108(6): 1104-8.

24. Francis $\mathrm{P}$, Berry V, Bhattacharya S, Moore A. Congenital progressive polymorphic cataract caused by a mutation in the major intrinsic protein of the lens, MIP (AQP0). Br J Ophthalmol. 2000;84(12):1376-9.

25. Brooks S, Ebenezer N, Poopalasundaram S, Maher E, Francis P, Moore A, et al. Refinement of the X-linked cataract locus (CXN) and gene analysis for CXN and Nance-Horan syndrome (NHS). Ophthalmic Genet. 2004;25(2):121-31.

26. Mahalakshmi B, Therese KL, Devipriya U, Pushpalatha V, Margarita S, Madhavan HN. Infectious etiology of congenital cataract based on TORCHES screening in a tertiary eye hospital in Chennai, Tamil Nadu, India. Indian J Med Res. 2010;131:559-64.

27. Oliveira ML, Giovanni ME, Porfirio Neto Jr F, Tartarella MB. Catarata congênita: aspectos diagnósticos, clínicos e cirúrgicos em pacientes submetidos à lensectomia. Arq Bras Oftalmol. 2004;67(6):921-6.

28. Birch EE, Wang J, Felius J, Stager DR Jr, Hertle RW. Fixation control and eye alignment in children treated for dense congenital or developmental cataracts. J AAPOS. 2012; 16(2):156-60.

29. Magli A, Fimiani F, Bruzzese D, Carelli R, Giani U, lovine A. Congenital cataract extraction with primary aphakia and secondary intraocular lens implantation in the posterior chamber. Eur J Ophthalmol. 2008;18(6):903-9.

30. Eventov-Friedman S, Leiba H, Flidel-Rimon O, Juster-Reicher A, Shinwell ES. The red reflex examination in neonates: an efficient tool for early diagnosis of congenital ocular diseases. Isr Med Assoc J. 2010;12(5):259-61. Comment in: Isr Med Assoc J. 2010;12(5):301-2.

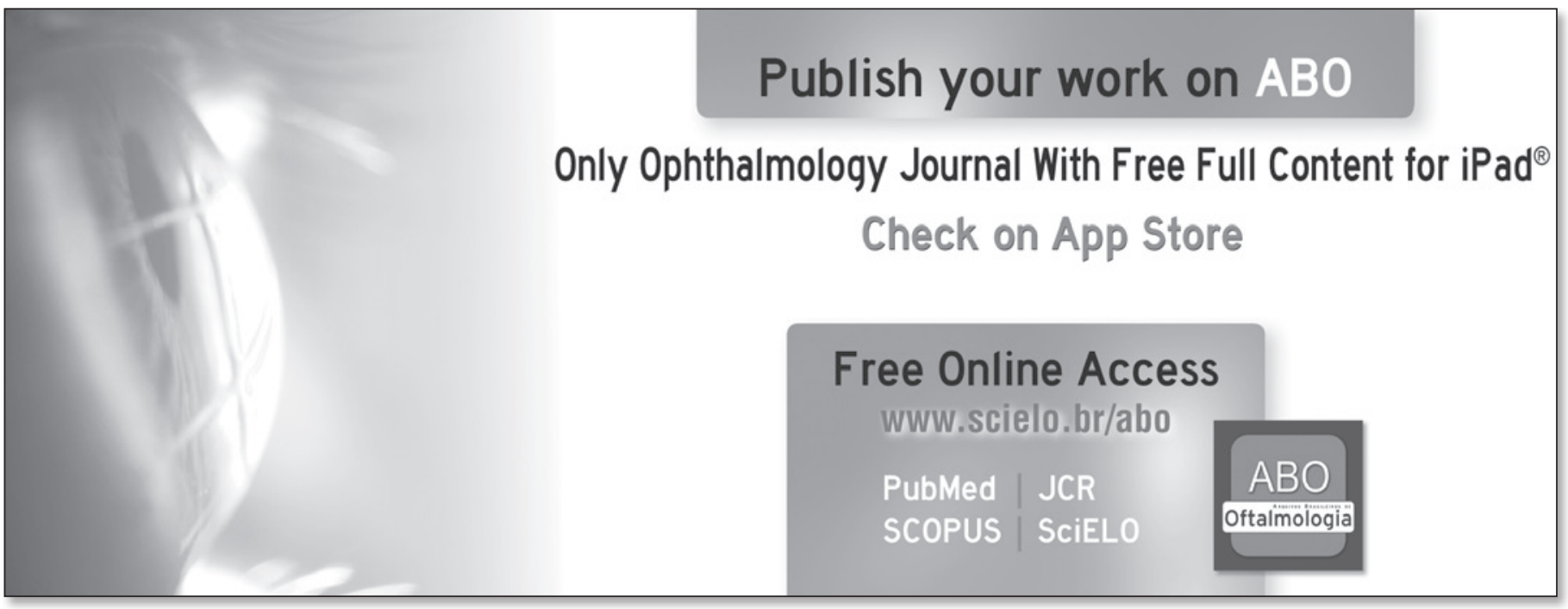

